\title{
Alergológica 2015: A National Survey on Allergic Diseases in the Adult Spanish Population
}

\author{
Ojeda $\mathrm{P}^{1}$, Sastre $\mathrm{J}^{2}$, Olaguibel $\mathrm{JM}^{3}$, Chivato $\mathrm{T}^{4}$ \\ On behalf of the investigators participating in the National Survey of the Spanish Society of \\ Allergology and Clinical Immunology Alergológica 2015.
}

\author{
${ }^{1}$ Clínica de Asma y Alergia Dres. Ojeda, Madrid, Spain \\ ${ }^{2}$ Servicio de Alergia, Hospital Fundación Jiménez Díaz, Madrid, Spain \\ ${ }^{3}$ Servicio de Alergia, Complejo Hospitalario de Navarra, Pamplona, Spain \\ ${ }^{4}$ Facultad de Medicina, Universidad San Pablo CEU, Madrid, Spain
}

J Investig Allergol Clin Immunol 2018; Vol. 28(3): 151-164

doi: 10.18176/jiaci.0264

\begin{abstract}
Background: The frequency of allergic diseases is increasing worldwide, particularly in industrialized countries. From a clinical, management, and public heath perspective, it is important to determine the reasons for consulting an allergist, the distribution by frequency of allergic diseases, and how health care is provided.

Objective: Alergológica 2015 was carried out to obtain information on clinical practice in allergy departments in Spain, and compare it with the previous study editions.

Methods: The data cover the year 2014 and the first quarter of 2015. The target sample was 6000 patients seen at public and private centers throughout Spain. A total of 500 allergists were invited to participate. Data were collected on an electronic case report form. Data were compared with the Alergológica surveys for 1992 and 2005 to identify differences.

Results: The final study population comprised 2914 patients (mean age 33.6 [18.9] years, 58\% women, $17 \%$ children), of whom $6.1 \%$ were foreign-born. The frequency distribution was as follows: rhinitis, 62\%; asthma, 23.4\%; drug allergy, 17.7\%; urticaria/angioedema, 11.5\%; food allergy, 10.4\%; contact dermatitis, 4\%; atopic dermatitis, 3\%; insect venom allergy, $2 \%$. A statistically significant increase was observed between data from 2005 and from 2015 with respect to the prevalence for allergic rhinitis, food allergy and drug hypersensitivity. An increase in the prevalence of a personal history of asthma, rhinitis, conjunctivitis, and eczema/atopic dermatitis were also observed. Besides, the number of relevant allergens in the same patient also increased. Most patients were referred from primary care, although a considerable percentage were referred by ENT specialists and dermatologists.

Conclusions: Increasing trends were observed for allergic rhinitis, drug allergy, and food allergy, and a decreasing trend was observed for asthma. Findings for other diseases remained practically unchanged. Allergic patients are increasingly complex and present with a myriad of atopic manifestations.
\end{abstract}

Key words: Allergic rhinitis. Allergic diseases. Asthma. Food allergy. Drug hypersensitivity. Epidemiology. Prevalence.

\section{Resumen}

Antecedentes: La frecuencia de las enfermedades alérgicas está aumentando globalmente, particularmente en los países industrializados. Desde una perspectiva clínica, de gestión y de salud pública, es importante determinar los motivos de consulta al alergólogo, la distribución de la frecuencia de las enfermedades alérgicas y cómo se presta la atención sanitaria.

Objetivo: Alergológica 2015 se realizó para obtener información de la práctica clínica en los servicios de alergia españoles y comparar sus resultados con los de las ediciones previas del estudio.

Métodos: Los datos cubren el año 2014 y el primer trimestre de 2015. La muestra diana fue de 6.000 pacientes atendidos en los centros públicos y privados de toda España. Se invitó a participar a un total de 500 alergólogos. Los datos se recogieron en un formulario electrónico. Se compararon los datos con lo de los estudios de los años 1992 y 2005 para identificar diferencias.

Resultados: La población final del estudio comprendió 2.914 pacientes (edad media 33,6 [18,9] años), 58\% de mujeres, 17\% niños) de los cuáles el 6,1\% fueron extranjeros. La distribución por frecuencia fue: rinitis en el 62\% de los sujetos; asma 23,4\%; alergia a fármacos 17,7\%; urticaria/angioedema 11,5\%; alergia alimentaria 10,4\%; dermatitis de contacto 4\%; dermatitis atópica 3\%; alergia al veneno de insectos 2\%. Comparativamente con los resultados obtenidos en Alergológica 2005 se observó un aumento estadísticamente significativo con respecto a la prevalencia de rinitis alérgica, alergia a los alimentos e hipersensibilidad a los medicamentos. También se observó un aumento en la prevalencia de antecedentes personales de asma, rinitis, conjuntivitis y eccema / dermatitis atópica. Además, el número de alérgenos relevantes en el mismo paciente también aumentó. 
La mayoría de los pacientes fueron remitidos desde atención primaria, si bien un porcentaje considerable lo hizo por el especialista ORL y dermatología.

Conclusiones: Se observaron tendencias al alza para rinitis alérgica, alergia a fármacos y alergia a los alimentos y una tendencia a la baja para el asma. Los hallazgos para otras enfermedades alérgicas quedaron prácticamente iguales. Los pacientes alérgicos son cada vez más complejos y presentan una diversidad de manifestaciones atópicas.

Palabras clave: Alergia a alimentos. Alergia a medicamentos. Asma. Rinitis alérgica. Epidemiología. Prevalencia.

\section{Introduction}

The frequency of allergic diseases is increasing worldwide, particularly in industrialized countries. From a clinical, management, and public heath perspective, it is important to determine the reasons for consulting an allergist, the distribution by frequency of allergic diseases, how the patient is referred to the specialist, and the diagnostic and therapeutic approaches used.

Allergy has been considered a full medical specialty in Spain since 1978, and the allergist is fully trained to treat all kinds of allergic diseases and allergic patients of all ages, from infancy to old age. Therefore, in 1992, the Board of Directors of the Spanish Society of Allergy and Clinical Immunology set up and carried out the first nationwide epidemiologic study, Alergológica 1992 [1]. Subsequent Boards of Directors published 2 new editions of this survey-Alergológica 2005 [2] and Alergológica 2015 — with the same scope and based on the same methodology in order to be able to compare data.

The 2015 edition also included 2 complementary surveys: the National Allergy Map and the National Pharmacy Survey. The first was addressed to all allergists in charge of allergy departments/units or private offices and inquired about material and human resources, diagnostic procedures, and availability of special therapies (eg, desensitization to drugs and/or foods), as well as educational and investigational activities. The National Pharmacy Survey was designed by a committee of the Spanish Society of Community Pharmacy and aimed at community pharmacists with the aim of knowing the allergy-related health and educational needs of people using a pharmacy [3]. In this study, we present the main results of the epidemiological survey Alergológica 2015 for the adult population. Findings for patients aged $<14$ years will be presented in a separate publication.

\section{Material and Methods}

The main objective of the study was to obtain information on clinical practice in allergy departments in Spain. Data were collected from patients consulting an allergist for the first time in 2014 and the first quarter of 2015 in order to determine variations compared with data reported in the reports Alergológica 1992 and 2005.

We performed a cross-sectional, epidemiological, observational study by prospectively collecting information on patients seen for the first time at an allergology clinic. The target sample was 6000 patients seen at both public and private centers from throughout Spain. The inclusion criteria were as follows: the visit had to be the first with the investigator for the current complaint (the same patient could have been seen by the same investigator previously, although not for the current complaint); the visit had to be a scheduled appointment chosen randomly for each investigator; informed consent for clinical information to be used for purposes of scientific research.

We invited a total of 500 board-certified allergists to participate. The allergists were selected from the list of members of the Sociedad Española de Alergia e Inmunología Clínica (SEAIC [Spanish Society of Allergy and Clinical Immunology]). The distribution was similar to that of the Spanish population and of local subpopulations.

Data were collected on an electronic case report form (CRF) that included general demographic data and data on impact on quality of life and work, as well as specific questions for each major allergic disease presented by the patient. The CRF remained open until the diagnostic work-up had been completed for all patients or until the end of the recruitment period.

Qualitative variables were expressed as relative frequencies with their 95\%CI. Quantitative variables were expressed as mean (SD); nonnormally distributed variables were expressed as median (IQR). Differences between qualitative variables were assessed using the chi-square or Fisher exact test. Quantitative variables were compared using the $t$ test or Mann-Whitney test. An analysis of variance (or Kruskal-Wallis test) was performed for multiple comparisons, complemented with a Bonferroni or Tukey test where necessary. Statistical significance was set at $P<.05$.

The study was authorized by the Clinical Research Ethics Committee of Hospital General de la Defensa, Madrid, Spain.

\section{Results}

\section{Study Sample}

Alergológica 2015 was based on data from 2914 patients seen at allergy clinics throughout Spain between January 1, 2014 and March 31, 2015, that is, 58\% of those seen in 2005 and $73 \%$ of those seen in 1992 . Foreign-born patients accounted for $6.1 \%$ of the population (vs $6.5 \%$ in 2005), and most were from Latin America, followed by North African and Arab countries and other minority population groups. The mean age of the study population (including children and adults) was $33.6(18.9)$ years (vs 32.1 [18.4] in $2005[P<.001]$ 


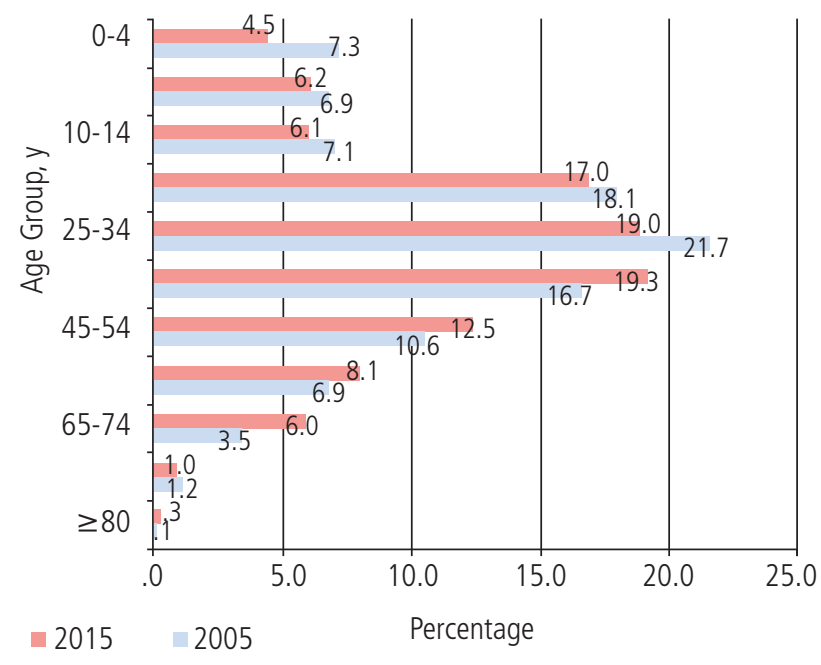

Figure 1. Age distribution (\%) of the patients participating in Alergológica 2015 and Alergológica 2005.

and 24.8 [17.8] in $1992[P<.0001])$ (Figure 1). Most patients were women ( $58 \%$ vs $42 \%$ ), and most lived in urban areas $(62 \%)$. As for socioeconomic characteristics, most patients had a medium-low level (48.8\%) and medium-high level (40.5\%). Slightly more than half of the study population reported a history of allergy among their immediate family (53\%); this figure was similar to those reported in the previous surveys.

Patients aged $\leq 14$ years accounted for $17 \%$ of the population. The mean age of this group was 7.6 (4.4) years (range, 4 months to 14 years), compared with 7.58 (3.9) in 2005.

It is noteworthy that the percentage of unemployed patients more than doubled between 2005 and 2015 (3.1\% vs 7.9\%). In $78.7 \%$ of cases, the patient was not occupationally exposed to allergens. In addition, the number of nonsmokers increased over the years ( $56 \%$ in 1992 to $70 \%$ in 2015 ).
The prevalence values of the different diagnoses varied widely between 2015 and 2005, with significant differences reported for rhinitis/conjunctivitis, bronchial asthma, food allergy, and drug hypersensitivity. In patients aged $>14$ years, significant differences were found for hypersensitivity to drugs $(17.7 \%$ vs $14.7 \% ; P=.0001)$ and to hymenoptera venom $(2.0 \%$ vs $1.5 \% ; P=.19)$ (Table 1$)$.

The vast majority of patients were seen in the public health sector $(81.4 \%)$. More than half of the patients $(60.2 \%)$ were referred from primary care (vs $52.6 \%$ in 2005). Only $15 \%$ were referred from other specialties (vs 43\% in 1992), and most of these were from the ear, nose, and throat (ENT) clinic (22\%).

\section{Rhinoconjunctivitis}

It is estimated that between $10 \%$ and $25 \%$ of the general public has rhinoconjunctivitis [4], although figures vary depending on the population studied and its geographic distribution. The prevalence of allergic rhinitis in adults in Western Europe has been reported to be around 25\% (21.5\% in Spain) [5].

Rhinoconjunctivitis was the main presenting complaint in Alergológica 2015, affecting 52.5\% of patients, which was slightly lower than in 2005 (55.5\%) and 1992 (57.4\%). However, a final diagnosis of rhinoconjunctivitis was established in $62 \%$ of patients (rhinitis alone [36.9\%], conjunctivitis alone [2.4\%]), as compared with $54.7 \%$ in Alergológica 2005. The frequency of rhinoconjunctivitis was 3 times that of bronchial asthma (21\%), the second most common presenting complaint in this edition of Alergológica (28\% in 2005). It is noteworthy that $17.5 \%$ of patients consulted for both diseases simultaneously (Figure 2).

The mean age was 29.9 (15.5) years. Most patients lived in an urban setting $(65.1 \%)$, with the remainder in semiurban areas $(24.3 \%)$, rural areas $(10.3 \%)$, and industrial areas $(0.35 \%)$. Patients lived with animals in $41.1 \%$ of cases $(44.6 \%$ in 2005), and in most cases these were pets, with dogs clearly more common than other animals (29\%). A family history of atopy - mainly rhinitis, asthma, and conjunctivitis - was

Table 1. Changes in the Prevalence of Established Diagnoses in Allergology Clinics in Alergológica 2015 and Alergológica 2005

\begin{tabular}{lccccc}
\hline \multirow{2}{*}{ Type of Allergy } & \multicolumn{2}{c}{ Alergológica 2015} & \multicolumn{2}{c}{ Alergológica 2005} & \multicolumn{2}{c}{$P$ Value } \\
& No. & $\%$ & No. & \% & .0001 \\
Rhinitis/conjunctivitis & 1617 & 62.0 & 2771 & 55.5 & .0001 \\
Bronchial asthma & 611 & 23.4 & 1396 & 28.0 & .5900 \\
Urticaria/angioedema & 299 & 11.5 & 551 & 11.0 & .3800 \\
Atopic dermatitis & 79 & 3.0 & 171 & 3.4 & .6700 \\
Contact dermatitis & 104 & 4.0 & 210 & 4.2 & .0001 \\
Food allergy & 271 & 10.4 & 369 & 7.4 & .0001 \\
Hypersensitivity to drugs & 463 & 17.7 & 735 & 14.7 & .19 \\
Hypersensitivity to insect venom & 51 & 2.0 & 77 & 1.5 & .01 \\
Other allergic diseases & 42 & 1.6 & 45 & 0.9 & .006 \\
Other nonallergic diseases & 113 & 4.3 & 290 & 5.8 & \\
Total patients & 2610 & & 4991 & & \\
\hline
\end{tabular}




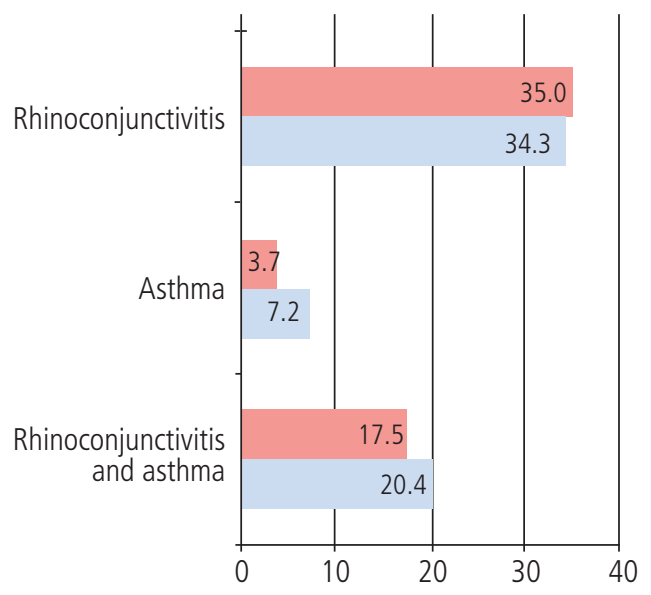

$=2015 \square 2005$

Figure 2. Distribution (\% of the total study population) of patients presenting only rhinoconjunctivitis, only asthma, and both rhinoconjunctivitis and asthma in Alergológica 2015 and Alergológica 2005.

recorded in $62.7 \%$. The percentage of smokers $(12 \%)$ was lower than in previous years.

We found that $70 \%$ of patients were referred to allergy clinics from primary care; this represents an increase over the previous 2 surveys. However, a notable decrease was observed in the number of patients referred from other specialists (from $43 \%$ in 1992 to $22.9 \%$ in 2005 and $10.9 \%$ in $2015 ; P<.0001$ [chi-square]). This change is very relevant, with the ENT physician being the specialist who referred the largest number of patients with rhinoconjunctivitis. In $76.2 \%$ of cases, the patient visited the doctor because of an exacerbation $(85.1 \%$ in 2005). The percentage of patients consulting for a first episode increased from $5 \%$ in 1992 to $14.9 \%$ in 2005 to $22 \%$ in 2015 ; these differences were very significant.

Patients had a 5-year history of rhinoconjunctivitis. At the time of the visit, the current episode had lasted 1.2 months. The etiology of rhinoconjunctivitis was allergic in $79.3 \%$ of patients (77.2\% in 2005), with the most common allergens being the same as those in previous editions of the survey. However, in the present edition, pollen was the most relevant allergen ( $70.8 \%$ vs $51.9 \%$ in 2005$)$, followed by mites, dander, and molds (Table 2). Two-thirds of patients were sensitized to 1 group of allergens, $23.3 \%$ to 2 groups, and $10.1 \%$ to $\geq 3$ groups (with "group" understood as a type of allergen, such as pollen, house dust mite, molds, and dander). Pollen was the only allergen involved in $42.2 \%$ of cases, house dust mite in $20.6 \%$, dander in $1.2 \%$, and molds in $0.9 \%$. Among patients with ocular involvement, the origin was allergic in $92 \%$.

According to the ARIA guidelines [4], allergic rhinitis was persistent in $66 \%$ of patients presenting with a first episode. In terms of severity, $29.9 \%$ had mild rhinitis, $59.7 \%$ moderate rhinitis, and $8.7 \%$ severe rhinitis. These findings are consistent with those from previous studies in Spain [6]. In the present survey, it was proposed to classify allergic conjunctivitis according to its duration and severity [7]. Consequently, conjunctivitis was intermittent in $50.6 \%$ of
Table 2. Relevant Allergens in the Etiology of Allergic Rhinitis

\begin{tabular}{|c|c|c|c|}
\hline Allergen & $\begin{array}{l}\text { Patients Ser } \\
\text { Alergológica } \\
2015\end{array}$ & $\begin{array}{l}\text { Alergológica } \\
\text { A2005 }\end{array}$ & $\begin{array}{l}\text { ch Allergen }{ }^{\mathrm{b}} \\
\text { Alergológica } \\
1992\end{array}$ \\
\hline \multicolumn{4}{|l|}{ Pollens } \\
\hline Grasses & 73.7 & 34.8 & 44.0 \\
\hline Olea europaea & 52.1 & 29.7 & 27.0 \\
\hline Cupressus species & 22.8 & 9.2 & - \\
\hline Platanus acerifolia & 14.2 & 7.7 & - \\
\hline Salsola kali & 13.1 & 7.2 & - \\
\hline Plantago lanceolata & 11.3 & 7.2 & - \\
\hline Parietaria judaica & 9.5 & 6.8 & 10.0 \\
\hline Chenopodium album & 8.5 & 9.5 & 6.4 \\
\hline Artemisia vulgaris & 5.8 & 6.8 & 8.0 \\
\hline Betula verrucosa & 1.6 & 0.7 & - \\
\hline Bushes & - & - & 2.3 \\
\hline Other & 3.7 & 2.9 & 7.0 \\
\hline \multicolumn{4}{|l|}{ Mites } \\
\hline $\begin{array}{l}\text { Dermatophagoides } \\
\text { pteronyssinus } \\
\text { Dermatophagoides }\end{array}$ & 41.7 & 39.3 & 51.0 \\
\hline $\begin{array}{l}\text { farinae } \\
\text { Lepidoglyphus }\end{array}$ & 31.8 & 31.5 & 41.0 \\
\hline destructor & 8.6 & 6.9 & - \\
\hline Blomia tropicalis & 5.6 & - & - \\
\hline putrescentiae & 3.5 & 5 & - \\
\hline \multicolumn{4}{|l|}{ Animal dander } \\
\hline Cat & 12.5 & 14.6 & 11.0 \\
\hline Dog & 9.9 & 10 & 7.5 \\
\hline Horse & 0.8 & 1.7 & - \\
\hline \multicolumn{4}{|l|}{ Molds } \\
\hline Alternaria & 5.8 & 6.1 & 5.0 \\
\hline
\end{tabular}

aMissing data were either not available or not reported in the study.

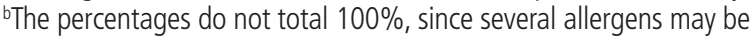
relevant in the etiology of allergic rhinitis in a specific patient.

patients and persistent in $48.8 \%$, mild in $50 \%$, moderate in $47 \%$, and severe in $1.6 \%$.

One novel aspect of the survey in comparison with the previous editions is the evaluation of quality of life in patients aged $>14$ years using the ESPRINT questionnaire [8], which examines 4 dimensions: symptoms, activities of daily living, sleep, and psychological aspects. The dimension most affected in patients with rhinitis was symptoms (mean score, 2.14), followed by sleep (mean score, 1.75).

The most widely used resources for diagnosis of rhinoconjunctivitis were the clinical history and physical examination (99.1\%). Skin prick tests were used in $97.5 \%$ of patients, and the most requested test was determination of $\operatorname{IgE}$ (total and specific) in $46.3 \%$.

As for therapy, antihistamines (mainly oral) were the most widely prescribed drug $(92.6 \%)$, followed by nasal corticosteroids $(70.6 \%)$. Avoidance of the allergen was recommended in $72.5 \%$ of patients, and specific immunotherapy was indicated in $31.3 \%$ (subcutaneous in $85.8 \%)$. 


\section{Bronchial Asthma}

A total of 618 patients $(21.2 \%)$ had bronchial asthma. This prevalence is considerably lower than in 1992 (35\%) and 2005 (28\%). According to data from the European Community Health Survey [9], the prevalence of asthma in Spain was low, although notable regional variability was observed (Albacete, 10\%; Barcelona, 5\%; Galdácano, 14.5\%; and Oviedo, 9.4\%) [10].

The mean age of patients with asthma was 29.5 (17.2) years, with peaks for children aged 5-15 years and adults aged $35-40$ years. Women accounted for $55 \%$ of cases. The area of residence was urban and semiurban for most patients $(59.1 \%$ and $20.8 \%$, respectively), in apartment buildings $(58.8 \%)$ and houses $(41.2 \%)$. Patients reported contact with animals (at home or otherwise) in $42.3 \%$ of cases (46.6\% in 2005 and $41 \%$ in 1992), with dogs being the most common pet (45.2\%).

Patients were generally referred from primary care $(74 \%$ vs $50.9 \%$ in 2005 ), mainly family doctors. The specialists who referred the patients to the allergologist were respiratory specialists (38.8\% vs $21.3 \%$ in 2005), ENT specialists (19.4\% vs $11.8 \%$ in 2005), and dermatologists (10.5\%). Most patients with asthma were nonsmokers, with only $17.2 \%$ being active smokers (14.4\% in 2005). Patients reported a family history (first-degree relative) of asthma in $39.3 \%$ of cases and rhinitis in $46.8 \%$. As for personal history, $20 \%$ of patients reported having being previously diagnosed with asthma and $16.5 \%$ with rhinitis. The main presenting complaints were dyspnea in $72.5 \%$, nasal symptoms in $73.4 \%$, cough in $64.3 \%$, breath sounds in $31.5 \%$, and ocular discomfort in $49.2 \%$.

Quality of life was generally good among patients with asthma, and findings were better for mobility and self-care among this group than in the general population.

Asthma was intermittent in $38.3 \%$ of cases and persistent in $57.5 \%$ (4.3\% did not respond). Figure 3 shows the classification of the patients by severity according to the Spanish Guidelines for Asthma Management (GEMA) [11].

Disease was controlled in $35 \%$ of patients. Control was classified according to the GEMA guidelines [11] as good in $35 \%$, partial in $31 \%$, and poor in $10 \%$ (28\% did not complete this section).

Asthma was extrinsic in $82.2 \%$ of patients and intrinsic in $16.8 \%$. Women accounted for $62.5 \%$ of cases of intrinsic asthma. Most patients with extrinsic asthma were sensitized to pollen, followed by house dust mite, and, at some distance,

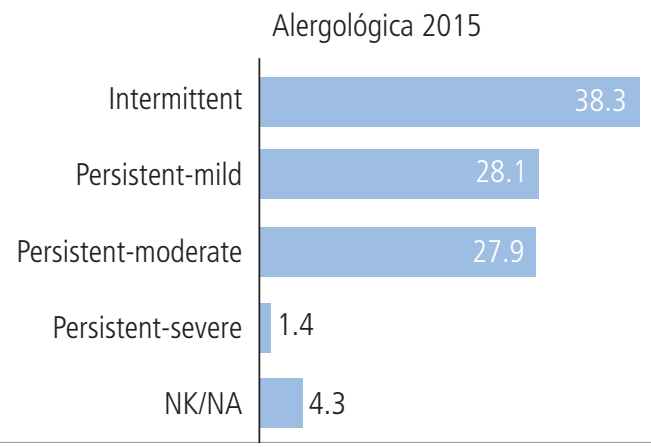

Figure 3. Classification of asthma severity in Alergológica 2015 according to the Spanish Guidelines for Asthma Management (GEMA) [11]. NK/NA indicates not known/not available. animal dander and other aeroallergens. The prevalence of sensitization to pollen increased by $50 \%$ between 2005 and 2015 (vs by $10 \%$ between 2005 and 1992) (Table 3). Analysis of the frequency of sensitization by region revealed 2 clear patterns: sensitization was mainly to house dust mites in coastal regions and the islands and to pollens in the interior. The geographic and climatic peculiarities of some areas (eg, Andalucía and Navarra) took the form of a mixed pattern, with high percentages of sensitization to both pollen and mites. Sensitization to animal dander (dog and cat) was highest in Madrid, La Rioja, and the Canary Islands, and sensitization to molds was highest in Murcia, Valencia, Extremadura, and Castilla-La Mancha.

The prevalence of occupational asthma was very low ( $1 \%$ vs $1.2 \%$ in 2005).

Asthma was associated with respiratory infection in $32.4 \%$ of patients and with rhinitis in $80.6 \%$.

The main parameters used to diagnose asthma were clinical history and physical examination (99.4\%), blood biochemistry and complete blood count (38.9\%), spirometry $(87.3 \%)$, bronchodilator response $(62.6 \%)$, skin test results (type 1, 77.1\%), fraction of exhaled nitric oxide (FeNO, $21.8 \%$ ), bronchial challenge $(6.7 \%)$, total $\operatorname{IgE}(46.5 \%)$, and specific IgE (48.6\%). Of note, the frequency of use of FeNO was significantly greater than in 2005 (1.9\%).

As for treatment, $91.3 \%$ of patients reported that they had received treatment during the previous year. Once the asthma work-up had been performed and the diagnosis confirmed, the main treatments prescribed were allergen avoidance $(73.3 \%)$, inhaled bronchodilators (78.6\%), topical corticosteroids alone (24.4\%), corticosteroids combined with long-acting ß-agonists $(51.8 \%)$, specific immunotherapy $(27.7 \%)$, antihistamines (41.6\%), and antileukotrienes (21.7\%). Omalizumab was prescribed to only $0.7 \%$ of those finally diagnosed with asthma. In $57.1 \%$ of cases, the allergologist made at least 2 changes in the treatment prescribed by the nonspecialist. The main changes included an increase in the use of inhalers with the combination of inhaled corticosteroids and longacting $\beta$-agonists (which increased by $33 \%$ [38.5\% in 2005]), increased prescription of antihistamines (41.6\% vs $29.8 \%$ in $2005)$, and the introduction of omalizumab, which was not recorded in 2005. All other therapeutic options remained practically unchanged compared with the previous survey.

Table 3. Positive Results in Tests With Aeroallergens in Extrinsic Asthma in Alergológica 2015 and Alergológica 2005

\begin{tabular}{lccc}
\hline Test & Alergológica 2015 & Alergológica 2005 & Change \\
\hline Pollens & $65.6 \%$ & $43.8 \%$ & $50 \%$ \\
Mites & $46.5 \%$ & $41.4 \%$ & $12 \%$ \\
Dander & $21.3 \%$ & $19.6 \%$ & $9 \%$ \\
Molds & $10.1 \%$ & $8.4 \%$ & $20 \%$ \\
Foods & $0.2 \%$ & $0.6 \%$ & $-67 \%$ \\
Insects & $0.0 \%$ & $0.2 \%$ & $-100 \%$ \\
Other & $0.4 \%$ & $1.1 \%$ & $-64 \%$ \\
\hline
\end{tabular}




\section{Drug Hypersensitivity}

Drug allergy was the third most frequent reason for visiting the allergologist. In 2015, a total of 544 patients consulted for possible drug allergy, that is, $18.7 \%$ of the study population (14.7\% in 2005). This percentage is indicative of the constant increase in this type of allergy since 1992 (12.6\%).

Mean age was 42.3 (20.1) years (41.4 [19.4] in 2005), which was higher than that reported for the general population (31.5 [18] years), probably owing to the lower number of children ( $9 \%$ vs $9.8 \%$ in 2005) among those who consulted for drug allergy (19.4\% vs $18.37 \%$ in 2005$)$. The percentage of children who consulted for drug allergy in 1992 was $12.5 \%$. Drug allergy was more prevalent in women (2:1 ratio). The percentage of patients with a family history of atopy was greater than in previous editions of the survey. The same was true for personal history ( $18 \%$ vs $2 \%$ in 2005 ).

It seems that an increasing number of patients are being referred from primary care $(65.2 \%$ vs $61.0 \%$ in 2005 and $55.0 \%$ in 1992). Patients were referred by other specialties, with most from the emergency department (14.9\%), internal medicine $(10.5 \%)$, dermatology $(8.8 \%)$, anesthesiology $(6.2 \%)$, respiratory medicine $(4.4 \%)$, and ENT $(1.8 \%)$. The mean time on the waiting list was 54.8 (66.6) days, although this tended to decrease (82 [114] in 2005 and 107 [158] in 1992). The visit was for a first episode of drug allergy in $79 \%$ of cases, which is clearly higher than that reported for other first visits $(P<.0001$, Fisher exact). The median time between the first reaction and the visit was 6.5 (0-600) months (20 [6-60] in 2005). The median time between the last reaction and the visit was 40 (20-100) days (90 [30-365] in 2005). The main reason for consultation was a probable drug reaction $(78.3 \%)$, followed by skin reactions $(17.8 \%)$.

Patients who consulted for drug reactions had a higher prevalence of comorbidities in all cases. In $27 \%$ of cases, the patient had another allergic disease. Diagnosis of drug allergy was confirmed in $16 \%$ (26.6\% in 2005) and ruled out in $29 \%$ (37.2\% in 2005). The diagnosis was suspected in $55 \%$ (36.2\% in 2005). The underlying hypersensitivity mechanism was immediate in $55.2 \%$, deferred in $3.8 \%$, delayed in $30 \%$, and other in $11 \%$. In children, the reaction was immediate in almost of half of the cases. Symptoms were mainly cutaneous (81.6\% vs $75 \%$ in 2005$)$, although anaphylaxis (8.1\%), asthma (3.9\%), and others were also reported (Table 4).

In $2015,45.7 \%$ of reactions were to $1 \mathrm{drug}(82 \%$ in 2005$)$, $44.2 \%$ were to 2 drugs ( $14 \%$ in 2005 ), and $10.2 \%$ were to 3 or more drugs $(4 \%$ in 2005). As in the previous editions of the survey, $\beta$-lactams and nonsteroidal anti-inflammatory drugs were the most frequently involved classes. Amoxicillin was the culprit drug in almost one-third of reactions. Comparative data are shown in Table 5.

Diagnosis was by skin prick test $(75.9 \%)$, intradermal test $(54.0 \%)$, patch test $(8.6 \%)$, drug challenge test $(62.5 \%)$, determination of $\operatorname{IgE}(22.2 \%)$, and other (unspecified) laboratory tests $(0.4 \%)$. A drug challenge test was performed in $70.2 \%$ of pediatric patients.

The main therapeutic approach was a written avoidance program $(96.3 \%$ vs $55 \%$ in $2005 ; 98.8 \%$ in cases of confirmed allergy and $95.8 \%$ in cases of suspected allergy [ $94 \%$ and $78 \%$, respectively, in 2005]). Ten patients underwent desensitization ( 3 in 2005). However, there are no data on the drug used for desensitization.

\section{Urticaria and Angioedema}

Of all the patients seen at allergy clinics during 2015, a total of $336(11.5 \%)$ were diagnosed with urticaria \pm angioedema. This finding was similar to that reported in 2005 (11\%). Although prevalence was slightly higher in the overall sample than in patients aged $<14$ years $(12.4 \%)$, the results are not statistically significant.

The mean age of patients with urticaria/angioedema was 36.8 (19.6) years, which was similar to that recorded in 2005 (35.75 [18.9] years). The number of females affected (64\%) was significantly higher than the number of males, and $28.1 \%$ of patients had pets at home (59.7\% in 2005).

As for family history, no differences were recorded between the overall sample and patients with urticaria/angioedema. The personal history of patients with urticaria/angioedema was similar to that of the overall population, with rhinitis and

Table 4. Clinical Manifestations of Drug Allergy ${ }^{a}$

\begin{tabular}{|c|c|c|c|}
\hline & Alergológica 2015 & Alergológica 2005 & Alergológica 1992 \\
\hline \multicolumn{4}{|c|}{ Exclusively cutaneous manifestations } \\
\hline Total & $81.6 \%$ & $75.0 \%$ & $79.0 \%$ \\
\hline Urticaria & $64.2 \%$ & $72.0 \%$ & $72.0 \%$ \\
\hline Angioedema & $32.7 \%$ & $42.0 \%$ & \\
\hline Fixed drug eruption & $1.7 \%$ & $2.0 \%$ & $6.0 \%$ \\
\hline Steven-Johnson syndrome & $0.2 \%$ & $1.0 \%$ & $1.0 \%$ \\
\hline Eczema & $2.2 \%$ & $6.0 \%$ & $2.0 \%$ \\
\hline Exanthem & $25.3 \%$ & & \\
\hline Anaphylaxis & $8.1 \%$ & $10.0 \%$ & $15.0 \%$ \\
\hline Asthma & $3.9 \%$ & $5.0 \%$ & $6.0 \%$ \\
\hline Rhinitis & $0.8 \%$ & $2.0 \%$ & \\
\hline Fever & $0.4 \%$ & $0.4 \%$ & $6.0 \%$ \\
\hline Other & $14.3 \%$ & $13.0 \%$ & $2.0 \%$ \\
\hline
\end{tabular}

aMissing data were either not available or not reported in the study. 
Table 5. Comparison of the Frequency Distribution of the Drugs Inducing Reactions in the 3 Alergológica Studies ${ }^{\mathrm{a}}$

\begin{tabular}{|c|c|c|c|}
\hline & Alergológica 2015 & Alergológica 2005 & Alergológica 1992 \\
\hline \multicolumn{4}{|l|}{ ß-Lactams } \\
\hline Total & $39.6 \%$ & $47.0 \%$ & $55.0 \%$ \\
\hline Penicillin & $8.7 \%$ & $13.0 \%$ & $28.0 \%$ \\
\hline Amoxicillin & $27.4 \%$ & $29.0 \%$ & $25.0 \%$ \\
\hline Other penicillin derivatives & $0.9 \%$ & $3.0 \%$ & \\
\hline Cephalosporins & $3.4 \%$ & $2.0 \%$ & $2.0 \%$ \\
\hline Clavulanic acid & $11.7 \%$ & & \\
\hline Carbapenems & $0.4 \%$ & & \\
\hline NSAIDs & $37.0 \%$ & $29.0 \%$ & $24.0 \%$ \\
\hline Pyrazolones & $9.6 \%$ & $10.0 \%$ & $16.0 \%$ \\
\hline Local anesthetics & $5.3 \%$ & $6.0 \%$ & $3.0 \%$ \\
\hline Quinolones & $4.3 \%$ & $3.0 \%$ & $1.0 \%$ \\
\hline Sulfonamides & $1.1 \%$ & $3.0 \%$ & $7.0 \%$ \\
\hline Macrolides & $3.2 \%$ & $3.0 \%$ & $3.0 \%$ \\
\hline Aminoglycosides & $1.1 \%$ & $2.0 \%$ & $3.0 \%$ \\
\hline Radiocontrast media & $4.2 \%$ & $2.0 \%$ & $<1.0 \%$ \\
\hline Tetracyclines & $0.2 \%$ & $1.0 \%$ & $3.0 \%$ \\
\hline Vitamins & $0.4 \%$ & $1.0 \%$ & $1.0 \%$ \\
\hline Hormones & $0.2 \%$ & $1.0 \%$ & \\
\hline Blood derivatives & $0.9 \%$ & $1.0 \%$ & $<1.0 \%$ \\
\hline General anesthetics & $0.8 \%$ & $1.0 \%$ & $1.0 \%$ \\
\hline Other & $17.7 \%$ & $11.0 \%$ & $9.0 \%$ \\
\hline
\end{tabular}

aMissing data were either not available or not reported in the study.

asthma being the most frequent diseases recorded. Only $18.4 \%$ of patients were smokers.

Most patients were seen in the National Health Service $(91.1 \%)$. Patients were referred by their primary care physician in $63.4 \% \%$ of cases and by another specialist in $17.1 \%$ of cases $(28.1 \%$ in 2005$)$, mainly from the emergency department (40.7\%) and dermatology department (33.3\%). Slightly more than half of consultations $(52.3 \%)$ were for a first episode, and $61.9 \%$ of patients presented with symptoms at the visit (61.3\% in 2005). Only $1.9 \%$ (2.6\% in 2005) consulted for anaphylaxis.

The impact on patient quality of life was evaluated using the EQ-5D-5L questionnaire [12], which revealed that, compared with the general population, patients with urticaria/angioedema were more affected in dimensions such as activities of daily living, pain/malaise, and anxiety/depression.

Urticaria was classified according to its duration, frequency, and cause. The most common type was acute urticaria $(57.7 \%$ of all patients who consulted for this reason), with a duration of $<6$ weeks; the remainder $(42.3 \%$ ) consulted for chronic urticaria. In the case of patients with chronic urticaria, $56.9 \%$ had recurrent flare-ups. No significant differences were detected with respect to the data obtained in 2005. Urticaria was the only presentation in $58.9 \%$ of patients $(56.8 \%$ in 2005$)$, and angioedema was the only presentation in $14.4 \%(12.3 \%$ in 2005). Both conditions presented simultaneously in $26.7 \%$ (30.8\% in 2005). Patients with acute urticaria were more likely to have a personal history of allergy in remission (48.5\% vs $9.1 \%[P=.03$, Fisher exact test $]$ ) and an active personal history (48.5\% vs $18.2 \%[P=.16$, Fisher exact test $])$.

In the vast majority of cases, urticaria was diagnosed using the clinical history and physical examination (90\%), as well as skin testing with food allergens (69\%) and aeroallergens (59\%). Various types of blood testing were used in approximately half of the patients. These findings differed from those reported for diagnosis of urticaria in 2005. However, in the case of patients with chronic urticaria, the work-up was performed based on an immunological study (almost 70\% [67.7\% in 2005]) and skin tests with food allergens $(70.4 \%[70.2 \%])$ and aeroallergens $(62 \%[62.5 \%])$. These findings were similar to those reported in 2005 .

Chronic urticaria was classed as idiopathic in $60 \%$ of cases. When the cause was known, this was identified as physical (including cholinergic urticaria) in $68.4 \%$ of patients. Alergológica 2015 reports a relevant finding that was not examined in 2005, namely, the percentage of patients who reported exacerbation with NSAIDs (20.83\% in acute urticaria and $19.3 \%$ in chronic urticaria). This finding is similar to those reported in the few available studies [13].

As for treatment, $83.3 \%$ of patients received antihistamines ( $73.3 \%$ in 2005 ). Of these, $72.6 \%$ were second-generation or nonsedating. Of note, almost $10 \%$ of patients $(17 \%$ in 2005$)$ made some adjustment to their diet, and almost $20 \%(9.1 \%$ in 2005) were prescribed corticosteroids. 


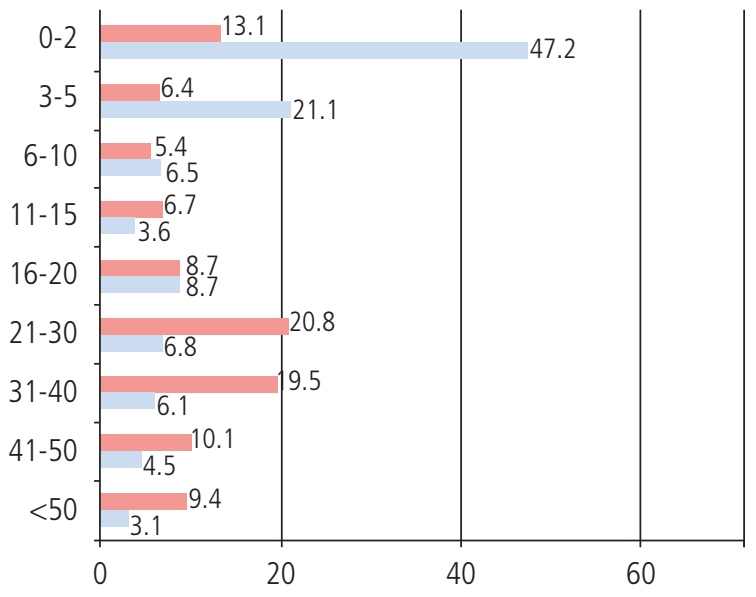

- Alergológica 2015 Alergológica 2005

Figure 4. Age distribution (\%) of the patients participating in Alergológica 2015 and Alergológica 2005.

\section{Food Allergy}

In 2015, the prevalence of food allergy in Spain among patients who visited the allergologist for the first time was $11.4 \%(7.4 \%$ in $2005[14,15])$. As in 2005 , food allergy was the fifth most common disease. The allergology study, which followed the same methodology as in 1992 and 2005, is a very useful approach for establishing trends in the frequency of the disease. A comparison of trends shows that the frequency of food allergy has increased by almost 3-fold in Spain in slightly over the last 2 decades from $3.6 \%$ in 1992 to $7.4 \%$ in 2005 to $11.4 \%$ in 2015 . The age distribution has changed as compared with Alergológica 2005 (Figure 4), with a decrease in infants and small children and an increase in young adults.

If we consider the suspected diagnosis (history and examination) with respect to the previous edition, we see that food allergy now includes an emerging disease, namely, eosinophilic esophagitis, which was the suspected diagnosis in $0.62 \%$ of patients who consult for the first time. Despite being an uncommon disease, eosinophilic esophagitis is frequently diagnosed in allergy clinics.

Patients with food allergy were aged between 0 and 69 years (mean, 25.4 [17.8] years), and more than half were women $(56.4 \%)$. A family history of atopy was reported in $64.7 \%$ of patients (in remission in $39.3 \%$ and active in $46.8 \%$ ). The personal history included allergy to other foods (15.1\%), followed by rhinitis $(23.9 \%)$ and atopic dermatitis $(11.5 \%)$.

More than half of the patients (54\%) were referred to the allergologist by a primary care physician (50.4\% in 2005); $30.8 \%$ were referred by other specialists (pediatrician in $15 \%$ [23.7\% in 2005]). Patients visited the allergologist of their own accord in $13.7 \%$ of cases (13.8\% in 2005). Two-thirds of patients $(65.4 \%)$ went to their primary care physician because of allergy during the previous 3 months, and $42.2 \%$ (52.1\% in 2005) had visited the emergency department because of allergy, with a mean frequency of $1.4(0.8)$ visits. The patient had consulted another specialist in $21.6 \%$ of cases.

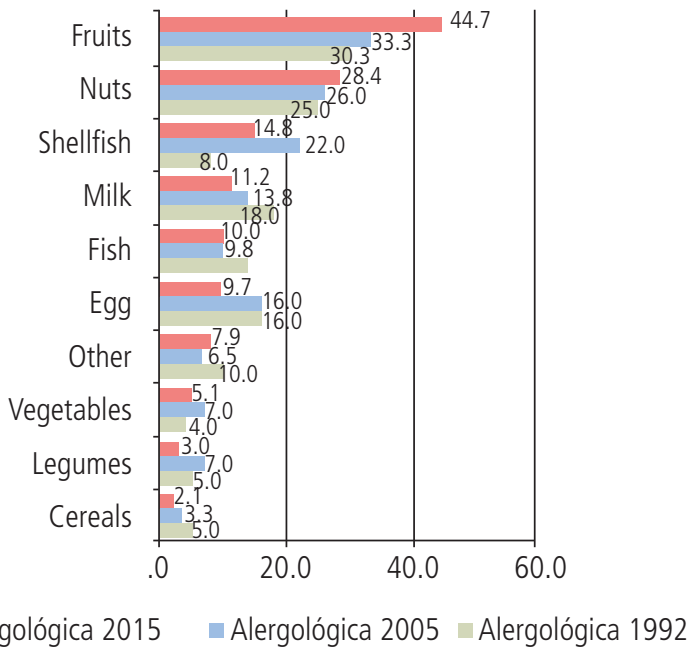

Figure 5. Distribution of the prevalence of allergy to the main food groups in Alergológica 2015, Alergológica 2005, and Alergológica 1992.

Parents had to miss a mean of 3.1 (2.1) days of work because of their children's food allergy in $18.5 \%$ of cases (17.6\% in 2005). Students missed a mean of 4.9 (4.7) days (median, 3 days) because of their allergy.

The main reason for consultation among food-allergic patients in 2015 was reactions to foods $(52.9 \%)$. The consultation was for a first reaction (flare) in $46.5 \%$ of cases (60.7\% in 2005), whereas in $53.5 \%$ of cases (39.3\% in 2005), the patient had had previous reactions.

The main causes of food allergy were fruits $(44.7 \%)$, tree nuts $(28.4 \%)$, and shellfish $(14.8 \%)$. Within the category of fruits, Rosaceae induced reactions in $59.4 \%$ of patients. Within the category of shellfish, $93.6 \%$ of reactions were caused by crustaceans. When the foods involved in the different age groups were compared between the 3 surveys (1992, 2005, and 2015), the percentages remained unchanged, as did the order of frequency (Figure 5).

The most common type of manifestation in food-allergic patients was cutaneous $(56.8 \%)$, followed by oral allergy syndrome (36.6\%), and digestive symptoms (18.7\%). Anaphylaxis was recorded in $12.1 \%$ of patients $(17.9 \%$ in 2005 ), asthma in $3.6 \%$, rhinitis in $3.3 \%$, and exercise-induced anaphylaxis related to food allergy in $1 \%$. In 2015, fish was the food that most frequently produced anaphylaxis.

A clinical history was taken and a physical examination performed in almost all patients with food allergy. Skin prick tests were performed in $94.8 \%$ (95.9\% in 2005), with no significant variations in their frequency of use according to the food. Specific IgE was determined in $67.8 \%$. An avoidance diet was used for diagnostic purposes in $29.1 \%$, and oral challenge tests were applied in only $15.6 \%$ (13\% in 2005). The diagnosis was based on the clinical history and presence of specific $\operatorname{IgE}$ to the food demonstrated in skin tests (mainly), serum, or both in at least $60.2 \%$ of cases.

The most frequent therapeutic approach was food avoidance (97.3\% vs $93 \%$ in 2005). Antihistamines were recommended in $80.7 \%$ (35.2\% in 2005) and corticosteroids in 
$45 \%$ ( $12.1 \%$ in 2005$)$. Of note, oral immunotherapy also began to be used, albeit in a very low percentage (3\%). Epinephrine auto-injectors were prescribed in $43.5 \%$ of cases (data not available for previous editions).

\section{Contact Dermatitis}

A total of 124 cases of contact dermatitis were diagnosed, that is, $4.3 \%$ of the total sample. This percentage was similar to that reported in $2005(4.2 \%)$ and higher than that reported in 1992 (2.4\%). Mean age was 44.4 years (42.6 in 2005). Contact dermatitis was twice as prevalent in women as in men.

The patient was in contact with allergens at work in $13.4 \%$ of cases and not in contact in $41.2 \%$. Homemakers and unemployed persons ( $12.4 \%$ and $7.7 \%$, respectively) accounted for a lower percentage of the total sample than patients with contact dermatitis ( $22.3 \%$ and $11.6 \%$, respectively). A personal history of eczema was recorded for $15.3 \%$ of patients, which is higher than in the other patients in the sample, of whom only $7.2 \%$ had a personal history of eczema.

The reason for consultation was a skin problem in $83.3 \%$ of patients. More than half were referred from primary care $(56.5 \%), 23.4 \%$ were referred from other specialists, and $11.3 \%$ consulted of their own accord. The main referring specialty was dermatology (75.9\%). Most patients diagnosed with contact dermatitis $(88 \%)$ had presented with classic dermatitis caused by contact with a substance. The origin was considered allergic in $54 \%$ of cases and irritant in $31.3 \%$. Photoallergy and phototoxicity were less common (3\%), as was dermatitis caused by an airborne agent $(4 \%)$ or medication $(9 \%)$. The origin was occupational in only $11 \%$ of cases. Most cases of dermatitis were classified as chronic $(51 \%)$, although up to $38 \%$ were classified as acute.

Diagnosis was mainly by taking a clinical history and performing a physical examination (92.44\%). In the case of contact dermatitis, it was mainly by specific tests $(83 \%)$, including patch tests in $76.5 \%$, photopatch in $2.5 \%$, and late-reading intradermal tests in $4.2 \%$ of cases. Patch tests were performed using a standard series in $91 \%$ of cases, with additional contact allergens used in 40\%. Patch testing was positive in $52.7 \%$ of patients assessed $(69.3 \%$ in 2005). The main causes of allergic contact dermatitis were nickel sulfate $(50.0 \%)$, potassium dichromate $(18.8 \%)$, methylchloroisothiazolinone + methylisothiazolinone (Kathon CG) $(11.4 \%)$, cobalt chloride $(9.1 \%)$, paraphenylenediamine $(6.8 \%)$, formaldehyde $(4.5 \%)$, quaternium-15 (4.5\%), and fragrances (fragrance mix I and fragrance mix II) $(2.3 \%)$. However, $20 \%$ of cases were caused by substances not included in commercially available series.

The most frequent recommendation for therapy was avoidance of the allergen in $75 \%$ of cases, followed by topical corticosteroids in $48 \%$. Calcineurin inhibitors were recommended in only $7 \%$ of patients. No treatment was prescribed in almost $8 \%$ of cases.

\section{Atopic Dermatitis}

In the present survey, a total of 98 patients $(56.5 \%$ females and $43.5 \%$ males; $60 \%$ children, $40 \%$ adults) visited the allergologist because of atopic dermatitis, that is, only $3.4 \%$ of the whole study population, as was the case in 2005
(3.4\%). Patients aged 0 to 5 years accounted for $28.6 \%$ of those affected, patients aged 6-15 years for $31.9 \%$, and patients aged $>15$ years for $39.6 \%$. The prevalence was $7.5 \%$ among foreign-born patients and $3.1 \%$ among Spanish patients. Onset was before 2 years of age in $47 \%$ of the sample and before 7 years of age in $74 \%$; however, the mean age at the first visit to the allergologist was 17.8 years.

Almost three-quarters of patients with atopic dermatitis (74.5\%) had a family history of atopy, and 58.2\% had a personal history of atopy. The disease involved was atopic dermatitis in $40.8 \%$, rhinitis in $17.4 \%$, conjunctivitis in $12.2 \%$, and bronchial asthma in $11.2 \%$. Only $7.1 \%$ of patients reported a personal history of food allergy in remission, and $6.1 \%$ reported an active history of food allergy.

Most patients were referred by their family physician $(32.6 \%)$ or pediatrician $(34.8 \%)$ and consulted mainly for cutaneous symptoms $(54 \%)$, although in $87 \%$ of cases these were associated with other symptoms, mainly respiratory symptoms.

The main diagnostic tests used were the prick test $(72.9 \%)$, followed by determination of serum total $\operatorname{IgE}(30 \%)$ and specific IgE (29\%). Patch testing with aeroallergens and foods was a novelty in 2005 compared with 1992 . In the present survey they were used in a small percentage of patients $(2.1 \%$ and $2.1 \%$, respectively). Oral challenge testing was used in $5.2 \%$ of patients with atopic dermatitis.

Atopic dermatitis was classified as idiopathic in $62 \%$ of cases (ie, equivalent to the nonatopic form of dermatitis), and in $38 \%$ of cases it was associated with allergens (ie, the atopic form). These percentages were similar to those recorded in 2005 (idiopathic, 58\%; allergens, 42\%) and 1992 (idiopathic, 57\%; and allergens, 43\%). Atopic dermatitis was considered to be idiopathic in $91 \%$ of patients who presented with dermatitis only.

Treatment of atopic dermatitis was mainly with moisturizing agents $(93.8 \%)$, followed by antihistamines $(62.5 \%)$ and topical corticosteroids $(61.4 \%)$. Topical calcineurin inhibitors were prescribed in $11.5 \%$ of patients $(31.0 \%$ in 2005$)$ and systemic corticosteroids in $5.1 \%$ (4.1\% 2015).

\section{Allergy to Hymenoptera Venom}

A total of 73 patients $(2.5 \%)$ were allergic to insect stings (77 [1.5\%] in 2005). Most patients were men aged 20 to 50 years. The area of residence was rural in $23.9 \%$ (33.3\% in 2005), and $45.7 \%$ lived in a house (45.3\% in 2005), as opposed to an apartment. A personal history of asthma was recorded in $6.9 \%$ of patients, rhinitis in $16.4 \%$, and atopic dermatitis in $1.4 \%$. These values are lower than those recorded for other allergic diseases.

Patients were referred from another specialty in $11.4 \%$ of cases; in $62.5 \%$, the specialty was emergency medicine (36.8\% of cases in 2005 were from the emergency department). Over half of the patients $(57.5 \%$ vs $73.5 \%$ in 2005$)$ visited the emergency department because of allergy during the previous year compared with $27.8 \%$ from the general sample $(P<.001$, Fisher exact test). Of those who attended, 5.5\% were subsequently admitted (1.9\% in the general sample). Mean time on the waiting list was 43.5 days (48 in 2005); $47.4 \%$ of patients were seen during the first month (50\% in 2005), and $75.9 \%$ were seen during the second month $(85 \%$ in 2005$)$. Diagnosis took a mean of 21.5 days (22.7 in 2005). 
Table 6. Insects Responsible for Reactions ${ }^{a}$

\begin{tabular}{lcc}
\hline & Alergológica 2015 & Alergológica 2005 \\
\hline Honeybee & 30.9 & 45.5 \\
Vespula & 29.4 & 27.3 \\
Polistes & 36.8 & 23.4 \\
Mosquito & 29.4 & \\
Other & 11.8 & \\
\hline
\end{tabular}

aMissing data were either not available or not reported in the study.

The insects involved are shown in Table 6. Eleven patients $(14.7 \%)$ had an association with beekeeping (14 in 2005 [18.7\%]). None were professionals (4 in 2005), 8 were amateur beekeepers ( 5 in 2005), and 2 were family members or friends of beekeepers. No response was provided in 1 case. No patients had a family history of allergy to hymenoptera venom (4 cases in 2005).

In 2015, most reactions were local reactions, whereas in 2005, most were diffuse skin reactions (grades I and II [22.4\% and 44.9\%]) and anaphylactic reactions (grades III and IV [16.3\% vs $16.3 \%]$ ). In slightly more than a third of cases $(38.4 \%)$, the reactions occurred in summer; in $31.5 \%$, they occurred in spring. Reactions to insect stings had already been recorded in $79.5 \%$ of patients $(65.8 \%$ local vs $13.7 \%$ general).

Diagnosis was based on the clinical history (97.1\%), skin tests $(61.4 \%)$, and determination of $\operatorname{IgE}(80 \%$ : total $[76.8 \%]$, specific [96.4\%], molecular [50\%]) and tryptase. Controlled sting test was not used in any cases as a diagnostic method.

Epinephrine was the treatment administered after the sting in 16 of the 70 cases $(22.9 \%)$ for which data were available. Thirteen $(18.6 \%)$ were managed in the emergency department during the previous year, and $2(12.5 \%)$ were admitted. Furthermore, $93.8 \%$ received antihistamines, and $15(93.8 \%)$ received corticosteroids. Epinephrine was recommended in $42.9 \%$ of cases $(55.8 \%$ in 2005$)$, and immunotherapy was recommended in $35.7 \%$ (49.4\% in 2005).

\section{Other Allergic and Nonallergic Diseases}

Other allergic diseases were diagnosed in 104 patients, that is, $3.6 \%$ of the population (45 patients [0.9\%] in 2005). Age ranged between a few months and 90 years, with a mean age of 40.4 (18.7) years. Males accounted for $49.5 \%$ of the group and women $50.5 \%$.

Patients consulted of their own accord (13.1\% vs $11.4 \%$ in 2005$)$ or were referred by their family physician $(50.5 \%$ vs $63.6 \%$ in 2005 ) or another specialist ( $31.3 \%$ vs $25 \%$ in 2005$)$. Of note, no cases were referred from internal medicine in 2015. The number of cases from pediatrics decreased considerably from $27.3 \%$ to $4 \%$. Also of interest is the notable increase in referrals by digestive specialists $(18.2 \%$ to $41.9 \%)$, possibly as a reflection of the recent considerable increase in the frequency of eosinophilic esophagitis and other digestive diseases with a possible allergic origin, thus leading to referral for an etiological study.

The 3 most frequent final diagnoses were nonspecified cough $(31.7 \%)$, contact dermatitis $(20.2 \%)$, and allergic

Table 7. Definitive Diagnosis in Patients With Other Allergic Diseases ${ }^{a}$

\begin{tabular}{|c|c|c|c|c|}
\hline & \multicolumn{2}{|c|}{ Alergológica 2015} & \multicolumn{2}{|c|}{ Alergológica 2005} \\
\hline & No. & $\%$ & No. & $\%$ \\
\hline Allergic bronchopulmonary aspergillosis & 0 & 0.0 & 0 & 0.0 \\
\hline Extrinsic allergic pneumonitis & 0 & 0.0 & 2 & 0.6 \\
\hline Pulmonary eosinophilia & 0 & 0.0 & 0 & 0.0 \\
\hline Drug-induced pulmonary infiltrates & 0 & 0.0 & 0 & 0.0 \\
\hline Idiopathic anaphylaxis & 4 & 3.9 & 7 & 2.1 \\
\hline Immunodeficiency & 0 & 0.0 & 1 & 0.3 \\
\hline Allergic gastrointestinal disease & 16 & 15.4 & 1 & 0.3 \\
\hline Cough of unknown origin & 33 & 31.7 & 17 & 5.1 \\
\hline Urticaria & 12 & 11.5 & 0 & 0.0 \\
\hline Gastroallergic anisakiasis & 0 & 0.0 & 10 & 3.0 \\
\hline Eosinophilic bronchitis & 0 & 0.0 & 0 & 0.0 \\
\hline Other & 0 & 0.0 & 23 & 6.9 \\
\hline Latex allergy & 9 & 8.7 & & \\
\hline Exercise-induced anaphylaxis & 3 & 2.9 & & \\
\hline Mastocytosis & 3 & 2.9 & & \\
\hline Contact dermatitis & 21 & 20.2 & & \\
\hline Diseases of the kidney and urinary tract & 5 & 4.8 & & \\
\hline
\end{tabular}

aMissing data were either not available or not reported in the study. 
Table 8. Definitive Diagnosis in Patients With Other Nonallergic Diseasesª

\begin{tabular}{lcccc}
\hline & \multicolumn{2}{c}{ Alergológica 2015} & \multicolumn{2}{c}{ Alergológica 2005} \\
& No. & $\%$ & No. & 10.7 \\
Upper airway obstruction & 11 & 9.7 & 36 & 0.0 \\
Cystic fibrosis & 1 & 0.9 & 0 & 18.2 \\
Respiratory infection & 15 & 13.3 & 61 & 0.0 \\
$\alpha$-1-Antitrypsin deficiency & 0 & 0.0 & 0 & 0.0 \\
Bronchial obstruction & 0 & 0.0 & 0 & 0.0 \\
Pulmonary embolism & 1 & 0.9 & 3 & 0.9 \\
Heart failure & 3 & 2.7 & 3 & 0.9 \\
Parasitosis & 2 & 1.8 & 0 & 0.0 \\
Pulmonary malformations & 0 & 0.0 & 4 & 1.2 \\
Otitis media & 2 & 1.8 & 1 & 0.3 \\
Iritis & 0 & 0.0 & 0 & 0.0 \\
Immotile ciliary syndrome & 0 & 0.0 & 0 & 0.0 \\
Pemphigus & 0 & 0.0 & 2 & 0.6 \\
Gluten sensitivity & 3 & 2.7 & 188 & 56.1 \\
Other & 84 & 74.3 & & \\
\hline
\end{tabular}

aMissing data were either not available or not reported in the study.

gastrointestinal disease (15.4\%). Table 7 shows the final diagnoses of other allergic diseases and compares their frequency with that of Alergológica 2005.

Other nonallergic diseases were diagnosed in 113 patients (3.9\%). Age ranged from 1 month to 90 years (38.6 [21.1] years). Patients attended of their own accord in $9.2 \%$ of cases or were referred by their family physician in $53.2 \%$ of cases. Referral was by another specialist in $28.4 \%$ of cases (ENT, $23.3 \%$; respiratory medicine, $20 \%$; and dermatology, $13.3 \%$ ); $9.2 \%$ were referred by a primary care physician.

The definitive diagnosis of other nonallergic diseases is shown in Table 8 . The percentage of "other diseases", that is, those that cannot be defined clearly, is noteworthy $(74.3 \%)$.

\section{Discussion}

The main objective of Alergológica 2015 was to obtain data from daily clinical practice on patients consulting an allergologist for the first time during the year 2014 and first quarter of 2015. The data were compared to identify differences with the surveys carried out in 1992 and 2005. Although the sample size was notably lower than that of previous studies (4005 patients in Alergológica 1992 and 4991 in Alergológica 2005 vs 2914 in Alergológica 2015), the statistical power was sufficient to allow for comparisons. The reasons for this lower recruitment rate may be the use of an electronic CRF for the first time in the latest edition, with technical access difficulties from many public centers, and the lack of budget for the investigators' remuneration.

The areas examined to investigate differences were the same as in previous editions and focused on epidemiology, seasonality, diagnosis (clinician involved and techniques used), and therapy for the different allergic diseases. Alergológica 2015 was based on data from almost 200 allergy clinics, two-thirds of which belong to the Spanish National Health System, the remainder being private centers. The geographical distribution of the patients included was representative of the Spanish population. Therefore, although the Alergológica studies are not population-based epidemiological studies that would yield prevalence data in the general population, they show the trends in allergic diseases over the last 20 years in Spain.

The most significant changes observed were for the prevalence of rhinoconjunctivitis, which increased, and the prevalence of bronchial asthma, which decreased. Significant increases in prevalence were also observed for food allergy, drug hypersensitivity, and other allergic diseases. The prevalence of other nonallergic diseases decreased significantly (Table 1).

As in previous editions, most patients were referred from primary care $(60.2 \%)$, potentially reflecting the higher number of joint activities between Spanish allergists and primary care physicians in the last decade. Notwithstanding, a considerable percentage $(15 \%)$ were referred by ENT specialists and dermatologists, which are the specialties most closely related to allergy. The fact that referrals from pediatricians have decreased may be due to the inclusion of fewer pediatric patients in the present edition.

In the case of rhinoconjunctivitis in particular, one of the most notable observations was that of a more diverse range of allergic manifestations in the same person. A statistically significant increase was observed between data from 2005 and from 2015 with respect to personal history of asthma, rhinitis, conjunctivitis, and eczema/atopic dermatitis. Besides, the number of relevant allergens in the etiology of allergic rhinitis in the same patient has also increased. This reflects the reality 
of observations from daily clinical practice, which show that allergic patients are more complex and present with a myriad of atopic manifestations. This observation also highlights the importance of treatment by a fully trained allergy specialist.

Data from the European Community Health Survey [9] show that the prevalence of asthma in Spain is low, albeit with notable regional variability [10]. Bronchial asthma was recorded in slightly more than $20 \%$ of the study population, which is considerably lower than in the previous surveys. The reasons for this are uncertain, although one explanation may be that education on asthma management among primary care physicians has improved considerably in recent years and many asthmatic patients are being treated in primary care. A key finding was the dramatic increase in the use of FeNO $(1.9 \%$ in 2005 vs $21.8 \%$ in 2015), although according to clinical practice guidelines [16], the technique is still considered inappropriate for phenotyping asthma. The use of other diagnostic tests remained largely unchanged, with the more notable differences being recorded for spirometry and the bronchodilator test (slightly increased).

Drug allergy was the third most frequent reason for visiting the allergologist, significantly more than for other first visits, and the frequency has increased gradually since 1992 (12.6\% vs $14.7 \%$ vs $18.7 \%$ ). In addition, more patients had a personal and family history of drug allergy than in previous surveys. $ß$-Lactams and nonsteroidal anti-inflammatory drugs continued to be the most involved drug classes.

Urticaria/angioedema is one of the most common complaints both in primary and in specialized care. Yet, there is a notable lack of published epidemiological data on this disease [17]. The prevalence of urticaria was similar to that detected in 2005, and the disease remains the fourth most common reason for visiting the allergologist after rhinitis, asthma, and drug allergy. Likewise, the care provided reflected that of Alergológica 2005, with an increased number of outpatient visits. Treatment of urticaria was similar to that reported in 2005, with the exception of prescription of corticosteroids, which more than doubled since 2005. Of note, treatment of chronic spontaneous urticaria with omalizumab was approved in Spain in January 2014 [18]. At that time, practice guidelines recommended the use of omalizumab as an alternative therapy when other immunosuppressants were not appropriate [19]. Therefore, it is very unlikely that this drug is prescribed to a patient attending an allergy unit for the first time, and this may explain why it was not recorded as a therapeutic option in Alergológica 2015.

Recent population-based studies [20-23] calculate the prevalence of food allergy to be $1 \%-3 \%$ of the population, although it can reach $8 \%$ in children aged $<3$ years. A comparative analysis of the 3 Alergológica studies revealed that the frequency of the foods involved remains unchanged. However, a gradual increase in the frequency of allergy to fruits and tree nuts and a decrease in allergy to milk and egg can be observed, while that of allergy to fish is maintained. The differences can be explained by the low percentage of pediatric patients (17\%). The median age in Alergológica 2015 was 33 years, and only $3 \%$ of patients were aged $<5$ years, which is the age group with the highest frequency of allergy to milk and egg.
Oral immunotherapy is becoming increasingly popular in more specialized allergy departments [24], although in the present study, it was administered in only $3 \%$ of cases. This treatment modality is not initially offered to a recently diagnosed patient. It is generally offered when the patient's progress has been followed over time and persistence of allergy is confirmed. In addition, since it is usually only administered to the age group most affected by allergy to egg or milk, ie, patients aged $<5$ years, the percentage of cases reported in the present study was very low $(3 \%)$.

The most interesting finding with respect to other allergic and nonallergic diseases in Alergológica 2015 was the absence of referral from the internal medicine department and the considerable decrease in the number of referrals from pediatricians $(27.3 \%$ to $4 \%)$. Also noteworthy is the increase in referrals from the digestive medicine department (18.2\% to $41.9 \%$ ), probably due to the prevalence detected in recent years of eosinophilic esophagitis and other gastrointestinal disorders with a possible allergic origin that require an etiological workup by an allergologist.

In the case of contact dermatitis, prevalence can be considered lower than expected, given that the prevalence of allergic contact dermatitis (sensitization to a specific contact allergen) in the general population is around $20 \%$ [25] or even $27 \%$ in the most recent European studies [26]. Also noteworthy is the low prevalence of contact dermatitis in persons aged $<18$ years, especially given that the prevalence of this disease has increased during the last decade [27]. Only $11 \%$ of cases were occupational. This low percentage is striking, since contact dermatitis is one of the most common occupational diseases. The explanation for this may be that patients with suspected occupational contact dermatitis may be referred from their primary care physician or from the medical surveillance service at their jobs to the dermatologist in the first place or to units specialized in this disease.

The prevalence of atopic dermatitis remained unchanged (3.4\% in 2015 and 2005) and was slightly higher than in 1992 $(2.5 \%)$. While this may seem low, stratification by age group reveals higher figures in children. Similarly, few changes were recorded with respect to type of referral (two-thirds from primary care physicians and pediatricians). Consistent with findings from other studies, more women had atopic dermatitis than men $[28,29]$. While sex does not seem to be an independent risk factor for atopic dermatitis [30], some authors report that women find it easier to describe their symptoms [31]. In addition, given that diagnosis is based on well-established clinical findings [31,32], it is striking that the disease was suspected in only $56.3 \%$ of patients. This could be explained by the fact that patients may not have had skin lesions at their first visit. In any case, the median time to diagnosis was 1 day, although diagnosis took more than 5 days in slightly more than $20 \%$ of cases, probably because of the presence of other allergic diseases requiring additional testing.

Allergy to hymenoptera venom was more prevalent among males ( $56 \%$ vs $42 \%$ ), because men are more likely to work in the open air and be beekeepers, and among people living in the countryside. Most patients were referred from the emergency department and had been treated with antihistamines, corticosteroids, and epinephrine. Consequently, the waiting 
list is shorter than in the general sample (43.5 vs 57.8 days), mainly because the reaction is acute and severe and must be managed as soon as possible with immunotherapy. In addition, allergologists are particularly sensitive to this condition.

In summary, Alergológica 2015 is the third edition of the Alergológica series, which was started by the Spanish Society of Allergy and Clinical Immunology in 1992. The study evaluates several areas of daily clinical practice in the treatment of allergic diseases presented by patients seen for the first time in allergy clinics. The study included 2914 patients from more than 200 allergy units in both the public and private health care systems in Spain. The results of the current edition show a similar distribution in the frequencies of allergic rhinitis, asthma, and drug allergy, which are the 3 main diseases diagnosed. Increasing trends were observed for allergic rhinitis, drug allergy, and food allergy, and a decreasing trend was observed for asthma. Findings for other diseases remained practically unchanged.

\section{Acknowledgments}

The authors acknowledge the altruistic contribution of all the participating investigators and of the patients, who gave their informed consent to participate. SEAIC also acknowledges the contribution of all the coordinators of the regional allergy societies in Spain and the supportive work of the CRO, Draft (Madrid, Spain). A list of all the investigators participating in the study as well as the study coordinators may be found in the Alergológica 2015 report at: http://www.seaic.org/inicio/ en-portada/alergologica-2015.html.

\section{Funding}

The study was funded by an unrestricted grant from FAES Farma (Bilbao, Spain).

\section{Conflicts of Interest}

The authors declare that they have no conflicts of interest.

\section{References}

1. Sociedad Española de Alergología e Inmunología Clínica. Alergológica. Factores epidemiológicos, clínicos y epidemiológicos de las enfermedades alérgicas en España. Madrid: Nilo Industria Gráfica; 1995.

2. Sociedad Española de Alergología e Inmunología Clínica. Alergológica 2005. Factores epidemiológicos, clínicos y epidemiológicos de las enfermedades alérgicas en España 2005. Madrid: Egraf SL; 2006.

3. Cristia E, Folgado JJ, Plaza FJ. Las enfermedades alérgicas en la farmacia comunitaria: Alergológica 2014. Farmacéuticos Comunitarios. 2015;7(2):5-13.

4. Bousquet J, Khaltaev N, Cruz AA, Denburg J, Fokkens WJ, Togias A, et al. Allergic Rhinitis and its Impact on Asthma (ARIA) 2008 update (in collaboration with the World Health Organization, GA(2)LEN and AllerGen). Allergy. 2008;63:8160.

5. Bauchau V, Durham SR. Prevalence and rate of diagnosis of allergic rhinitis in Europe. Eur Respir J. 2004;24:758-64.
6. Mullol J. A survey of the burden of allergic rhinitis in Spain. J Investig Allergol Clin Immunol. 2009; 19(1):27-34.

7. Sánchez-Hernández MC, Montero J, Rondón C, Benítez del Castillo JM, Velázquez E, Herreras JM, et al. Consensus document on Allergic conjunctivitis (DECA). J Investig Allergol Clin Immunol. 2015;25(2):94-106.

8. ESPRINT Study group and Investigators, Valero A, Alonso J, Antepara I, Baró E, Colas C, et al. Development and validation of a new Spanish instrument to measure health-related quality of life in patients with allergic rhinitis: the ESPRINT Questionnaire. Value Health. 2007;10:466-77.

9. Janson C, Anto J, Burney P, Chinn S, de Marco R, Heinrich J, et al. The European Community Respiratory Health Survey: what are the main results so far? European Community Respiratory Health Survey II. Eur Respir J. 2001;18:598-611.

10. Grupo Español del Estudio Europeo del Asma. El Estudio Europeo de Asma. La prevalencia de síntomas relacionados con el asma en 5 regiones de España. Med Clin (Barc). 1995;104:487-92.

11. Guía Española para el Manejo del Asma (GEMA). Grupo Español para el Manejo del Asma. Barcelona: Ediciones Mayo; 2003.

12. Garcia-Gordillo MA, Adsuar JC, Olivares PR. Normative values of EQ-5D-5L: in a Spanish representative population sample from Spanish Health Survey, 2011. Qual Life Res. 2016;25:1313-21.

13. Sanchez-Borges M, Caballero-Fonseca F, Capriles-Hulett $A$, González-Aveledo L. L. Aspirin-exacerbated cutaneous disease (AECD) is a distinct subphenotype of chronic spontaneous urticaria. J Eur Acad Dermatol Venereol. 2015;29:698-701.

14. Caballero Martínez F. Alergológica 2005. Methodological Aspects and Sample Characteristics of the Study. J Investig Allergol Clin Immunol. 2009;19 Suppl 2:2-6.

15. Fernández Rivas M. Food Allergy in Alergológica-2005. J Investig Allergol Clin Immunol. 2009;19 Suppl 2:37-44.

16. GEMA 4.2 Guía española para el manejo del asma. Executive Committee of GEMA. Luzán 5, Editors. 2017, Madrid, Spain.

17. Ferrer M, Bartra J, Giménez-Arnau A, Jauregui I, LabradorHorrillo M, Ortiz de Frutos J, et al. Management of urticaria: not too complicated, not too simple. Clin Exp Allergy. 2015;45(4):731-43.

18. Newsletter of the Spanish Drugs and Health Products Agency, January 2014. https://www.aemps.gob.es/informa/boletinesAEMPS/boletinMensual/2014/enero/boletin-enero.htm

19. Bernstein JA, Lang DM, Khan DA, Craig T, Dreyfus D, Hsieh $F$, et al. The diagnosis and management of acute and chronic urticaria: 2014 update. J Allergy Clin Immunol. 2014;133(5):1270-7.

20. Rona RJ, Keil T, Summers C, Gislason D, Zuidmeer L, Sodergren $E$, et al. The prevalence of food allergy: a meta-analysis. J Allergy Clin Immunol. 2007;120(3):638-46.

21. Zuidmeer L, Goldhahn K, Rona RJ, Gislason D, Madsen C, Summers $C$, et al. The prevalence of plant food allergies: a systematic review. J Allergy Clin Immunol. 2008;121(5):12108.

22. Mills EN, Mackie AR, Burney P, Beyer K, Frewer L, Madsen C, et al. The prevalence, cost and basis of food allergy across Europe. Allergy. 2007;62(7):717-22.

23. Nwaru BI, Hickstein L, Panesar SS, Muraro A, Werfel T, Cardona $\mathrm{V}$, et al. The epidemiology of food allergy in Europe: a 
systematic review and meta-analysis. Allergy. 2014;69(1):6275.

24. Nurmatov U, Dhami $S$, Arasi $S$, Pajno GB, Fernandez-Rivas $M$, Muraro A, Roberts $G$, et al. Allergen immunotherapy for lgEmediated food allergy: a systematic review and meta-analysis. Allergy. 2017;72(8):1133-47.

25. Thyssen JP, Linneberg A, Menné $T$, Johansen JD. The epidemiology of contact allergy in the general populationprevalence and main findings. Contact Dermatitis 2007; 57:287-99.

26. Diepgen TL, Ofenloch RF, Bruze $M$, Bertuccio $P$, Cazzaniga $S$, Coenraads PJ, et al. Prevalence of contact allergy in the general population in different European regions. $\mathrm{Br}$ J Dermatol. 2016;174:319-29.

27. Belloni Fortina A, Romano I, Peserico A, Eichenfield LF. Contact sensitization in very young children. J Am Acad Dermatol. 2011;65:772-9.

28. Odhiambo JA, Williams HC, Clayton TO, Robertson CF, Asher MI, Group IPTS. Global variations in prevalence of eczema symptoms in children from ISAAC Phase Three. J Allergy Clin Immunol. 2009;124:1251-8.e23.

29. Burr ML, Dunstan FD, Hand S, Ingram JR, Jones KP. The natural history of eczema from birth to adult life: a cohort study. $\mathrm{Br} J$ Dermatol. 2013;168:1339-42.
30. Schäfer T, Heinrich J, Wjst M, Krause C, Adam H, Ring J, et al Indoor risk factors for atopic eczema in school children from East Germany. Environ Res. 1999:81:151-8.

31. Remes ST, Korppi M, Kajosaari M, Koivikko A, Soininen L, Pekkanen J. Prevalence of allergic rhinitis and atopic dermatitis among children in four regions of Finland. Allergy. 1998:53:682-9.

32. Hanifin JM, Rajka G. Diagnostic features of atopic dermatitis. Acta Derm Venereol. 1980;92:44-7.

Manuscript received March 23, 2018; accepted for publication April 10, 2018.

\section{- Pedro Manuel Ojeda}

Clínica de Asma y Alergia Dres Ojeda

C/ Oquendo, 23

28006 Madrid, Spain

E-mail: pedro.ojeda@seaic.org 